Portland State University

PDXScholar

1974

\title{
An Exploratory Study to Assess Client Expectancy of Counseling Gain
}

William W. Hanselman

Portland State University

Follow this and additional works at: https://pdxscholar.library.pdx.edu/open_access_etds

Part of the Social Work Commons

Let us know how access to this document benefits you.

\section{Recommended Citation}

Hanselman, William W., "An Exploratory Study to Assess Client Expectancy of Counseling Gain" (1974). Dissertations and Theses. Paper 1737.

https://doi.org/10.15760/etd.1736

This Thesis is brought to you for free and open access. It has been accepted for inclusion in Dissertations and Theses by an authorized administrator of PDXScholar. Please contact us if we can make this document more accessible: pdxscholar@pdx.edu. 
AN EXPLORATGRY STUDT TO ASSESS

CIIEIM ERPEOTANCY OF COJMSELIIG GAIN

by

HILIAM W. HANSELMAN

A report submitted in partial fulfiziment of tise requirements for the degree of

MASTER OF SOCIAL WORK

Portland State University

1974 
APPROVED:

Frank F. Miles, School of Social Work 
This exploratory study is designed to investigate the rolo of precounseling client expectancy as it affects the outcome of initialinterviey counseling. To facilitate invastigation into this area it vas necessary to develop a measuring instrument whereby an individual's expectation of the success of counseling could be assessed. This Instrument was then administered to beginning clients at two counseling facilfties. 
TABIE OF CONTENTS

Pags

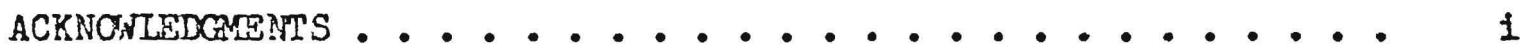

LIST OF TABLES ......................... ii

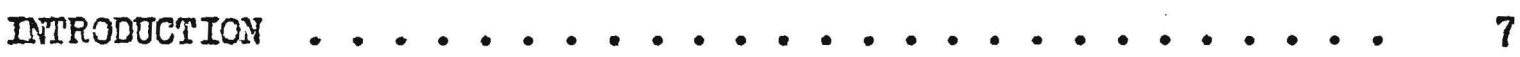

The Problem

RESEARCH DESIGN AND METHODOLCGT . . . . . . . . . 9

Setting

Sample

Adninistration of Instrument

Scoring

RESULTS $\ldots \ldots \ldots \ldots \ldots$

Table 3 Conclusions

DISCUSSION

Statistical Considerations

Further Analysis and Research Needed

Concluding Comments

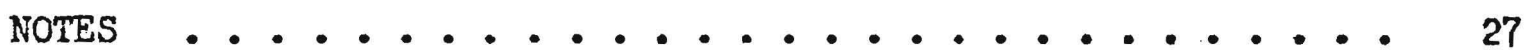

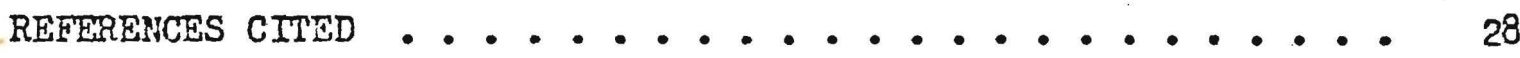

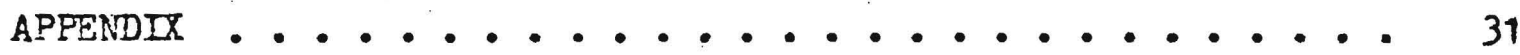




\section{ACKNOWLEDCWENTS}

I wish to express my appreciation to the staffs at ifultnomah County Family Serrices and the Portland State University Counseling Center for taking the time and effort to perform the actual research. 


\section{LIST OF TABLES}

Table

Page

$1 \quad$ Expectancy Scale Sumary

Multnomah County Family Services ........ 15

2 Expectancy Scale Summary

Portland State University Counseling Center ... 16

3 Results of $T$ Tests and F Tests

from the Data of Table 1 and Table 2...... 17 


\section{INTRODUCTION}

The question of the role of the various "non-specific" factors in psychotherapy has long been the subject of conjecture and study. One such element which has been suggested as an important component of psychological treatinent is that of "expectancy of therapeutic gain." This rather vaguely defined exolanatory constmet has intuitive apoeal and has prompted numerous research efforts aimed at the discorery of its contribution to the therapeutic process.

Expectancy (or instrumentality) theory has ofien been used as the basis of research attempting to relate attitudes and behavior. Some writurs treat expectation $3 s$ a "trait" which individuals bring to the counseling session and others treat it as a "state" to be experimentally Induced by the researcher. As is quite often the case with attitudebehavior imvestigations there has been a lack of significant resulta.

A number of different sspects of the expectancy construct in relation to psychotheraoy have been deflned and investigated. The works of Apfelbaum (1958), Goldstain (1960), and Sloane et al. (1970) hara served to define reievant dimensions and to highlight the inportance and meaningfulness of the rois expectancies of the particioants in osychotherapy.

Data obtained by Chance (1959) indicate that therapist prognostic expectancies may be a factor of major proportion in theraog outccma. This study demonstrated that therapists with more optinistic expectations for success brought about more positive change in their patients 
than did therapists with a less optimistic bias, given equal levels of patient psychopathology. The influence of therapist expectations has been thoroughly documented by Rosenthal (1966) and discussed by Pope et al. (1972) and by Wilkins (1971, 1973). Bednar (1970) goes as far as to suggest that the success of psychotherapy

... is not a result of the validity of specific counseling procectures; rather it is because of the actual irrelevance of the specific counseling methods emploged.

He concludes that improrement happens

... as long as each counseling system successfully imparts to the client the expectation that he should be improving as a result of the expert treatment he is receiving. (pp. 651-652)

Klein et al. (1969) commented upon how much the client's expectations are influenced by the direct and intended actions of even behavior therapists.

Here the therapist tells the patient at length about the power of the treatment method, pointing out that it has been successful with comparable patients and all but promising similar results for hin too.

Indeed it seened to us that treatment plans and goals were laid out in such a detall that the patient was taught precisely how things would proceed and what responses and changes were expected of him all along the way. (p. 262)

In a major investigation, Iennard and Bernstein (1960) found evidence strongly suggestive of the importance of the congrufty or mutuality of therapist-patient expectations concerning in-therapy roles and communications. They concluded that

... when there is any degree of discrepancy or lack of consensus between the participants, and thetr expectations are dissinilar ... manifestations of strain appear in their interpersonal relations. If 
the expectutions are too dissimilar, the ... system disintegrates unless the differences can be reconciled. (D. 153)

A study by Iipkin (1954) supports the notion that a patient who is "positively oriented" toward therapy and who expects success will make more gains than a patient who has reservations. It is this last mentioned aspect of expectation, the patient's (client's) expectation of success of treatment, with which this paper is concerned.

Rosenthal and Frank (1956) argue that patients entering psychological treatment have varjing levels of expectation concerning the success of treatment, and that these expectailons may have much to do with the outccme of treatment. Although there is much theoretical and intuitive support for such an idea (Relley 1949, Cartiright and CartFright 1958, Goldstein 196́2), research evidence to date has not be mequirccal. (Goldstein, for example, has even shown this to be the case when little or no therapy occurs. He followed a group of patients who had been seen only for intake interview, placed on a waiting 1ist, and who never had therapy at all. Fe discorered that a large proportion of them had symptcmatic improvement proportionate to their expectation of help from their intended treatment at the tire of their initial contact). In survejing mumerous studies which have investigatad the phenomanon (Brady et al. 1950, Heine and Trosman 1960, Trank 1968), one Finds tivat, in general, the authors express confidence in the valldity of the relationship, Jet no firn evidence for the positive relation of patient expectation and sutcome has been found.

Following investigation concerned with the ebore problem this writer is in agreement with Jikins (1973) when he says 
It appears from the literature reviewed that the construct "expectancy of therapeutic gain" emerged prematurely and without the empirical support, necessary to establish its ralidity. (p. 75)

Inspection of a representative research effort in this area sheds some light on a likely factor contributing to the dearth of positive results. For example, in a study by Brady et al. (1960) a high expectation and low expectation group were compared in tems of treatment success. At termination, the growps were not found to differ in therapist ratings of improvement. Such a finding argued for rejection of the hypothesized relation betreen patient expectation of success and actiral outcome.

This study can be criticized with regard to the assessment of expectation. Brady used two projective measures of attitudes toward psfchiatric hospitals (the Plcture Attitudes Test and the Sentence Completion Attitude Test devaloped by Reznikoff et al., 1959) in order to assign subjects (hospitalized patients) to a high or low expectancy group. It is of considerable question whather attitudes toward hospitals (or other treatment centers) in general can appropriately be used as accurate estimators of specific expectancy of success. Impirical data bearing upon this objection were provided by wicker (1969). In this study, students' attitudes toward scientific researeh in general were found to be unrelated to the extent of their participation as subjects in a psychology experiment, while more specisic attitudes toward participating 99 a subject in pogchological research had a significant positive relationsip with extent of actual partialpation.

Eramination of the relevant literature reveals that other studies 
in the area of expectation of treatment success have shared similar weaknessas in the area of assesment. Typically, one of four aporoaches has been employed in dealing with this problera. One was that used by Brady et al. (1950), whereby an attitude scale was assumed to be an estinator of expectancy level. The inajor objection to this approach has been noted above.

Another method of dealing with the concept of expectation of success involves an attempt at the experinental manipulation of its level (Frank et al. 1959). Theoretically this approach is quite sound; the problem would appear to be a practical one. Usually the effectivaness of the manipulation (e.g., a therapist tolling the client the treatinent is good cr bad) is simply assumad and no attempts are made to determine if, and to what extent, the manfpulation works. A2so, such an approach does not allew for individual differences in reaction to the treatment. It has been damonstrated that some subjects respond well to an attempt at expectancy manipulation while others do not (Gliedman et al. 1958).

A third approach to the assessment of expectancy is just to ask the client if he expects to get well. Although this method has the virtue of directness, it is doubtful whether it can actually be of use to the researcher. Such a factor as willingness to adopt the "sick" role could eastly confound the level of expectation obtainad oy the use of direct questioning.

A fourth approach, a modirication of the direct wethod, whereog the client makes a number of statements concerning sympton distress, has been employed in a number of studies (Goldstein and Shipman 1951, Fiper 
and Wogan 1970). The investigation of Goldstein and Shioman was 1llustrative of this method. Prior to treatment patients were given a symptom checklist to complete. This checklist was concerned with the patients perception of self as related to two time dinensions; these being his current perception of self ("present self") and the person he expected to be following treatiment ("expected self"). Difference scores betreen present and expected ratings of spmotoms constituted the operational definition of expectancy level for each subject.

This experimental method, of the four, contains the lesser magnitude in terms of objections and appears to yield the most acceptable measure of expectancy. Next, this method can readily be expanded to include both client and counselor post-treatment measurement. Thirdly, avoided are the difilculties inherent in attempting to assess the individual's attitudes through projective-type measures. Further, and perhaps just as important, there is no attempt mada to manipulate the client through trying to artificially bring abcut an experinentaliy Induced expectancy "state" for research purposes.

For these reasons this conceptual approach is employed in the present study. However, in exanining this method for suitability, a number of problems soon become evident. These revolve abouts

The Pating Process. The way in which a person perceives his problems may be affected by the process of going through the questionnalro.

Timing. A person experiencing significant psychological distortion at the tine of completing the questionnaire may well lack the perspective nocessary for accurately responding to the items. 
Consistency. The clieat's efforts to appear consistent to the counselor may lead to reporting a fulfillment of expectancy (e.g., synptom reduction) similar to the one he states he expected.

Initial Expectancz. Persons with high discomfort (sympton Intensity) will be able to report marked improvement while those with lesi Initial discomfort can only have low expectancy and therefore low actual therapeutic gain. Bearing this in mind it then becones possible that any difference in gain between the two groups with high and Iow expectations will be exaggerated by the difference in the initial scores of their members, unless relative or corrected measures are used.

\section{The Problem}

A searci of the literature has revealed that, although mang scalas for the assezsment of various different aspects of expectancy exist, there is no generaliy accepted measure of the expectation of success. It is clear tinat there is great reed for an econonical, objective, reliable, and valid instrument to assess an individual's expectation of the success of counseling. The lack of such a tool must inevitably slow progress in this area of research and, to the extent that expectancy plays an imoortant role in counseling, the lack of such a basic measure clouds important aspects of the general area of measurement of counseling efiectiveness (e.g., counseling outcome as related to expectancy).

The scope of the present study does not permit the large-scale sampling and data collection necessary to validate such an instrument. It is believed, however, that further research effort in this area is Justlified dus to the equirocable nature of the conclusions reached thus 
far regarding expectancy. The current investigation is, therefors, concerned with the develooment of an economical measure of an indiridual counselee's expectation of the success of counseling for his presenting problems. It is the author's opinion that devalopment of a meaningiul Index, with appropriate measures, regarding client expectancy will yield a useful tool for counselors-in-training as well as for further use in research. 


\section{RESEARCH DESIGN AND METHODOLCGY}

\section{The Exroectanct Measure}

The first step in the deralopment of the instrument involved the generation of an item pool. This was accomolished intuitively, whereby questions appearing relevant to the construct to be assessed were formulated by the author. Many of the ideas for the items are found in the Iiterature of those doing research in the same or related areas. After discussion with several pspchologists, counselors, and socisl workers, 25 items which were clear, unambiguous, and contained only one idea per item were selected for inclusion in the initial pool. The items each consisted of an single statement or question followed by four alternative responses or ways of completing the statement. The alternatives were designed (with the exception of the non-expectancy, informational questions) so that each seemed to represent a difierent level of expectation. For each item the alternatives were ranked in order from high to los expectancy. For scoring purposes the alternatives for each item were assigned an integer valus (1, 2, 3, or 4) in accordance with their raniking; a weighting of one indicating the alternative ranked lowest, on up to four indicating the alternative ranked hignest. Total expectancy score was defined as the sun of the values of the alternative chosen for each item.

Following pretesting the quastionnaire was reduced to 22 items. In final form the rankad alternatitas were presented in either ascending or descending order of expectancy. For exanple, the item which asked 
for an estimate of the need for future counseling, the response order is: derinitely will, probably will, probably will not, definitely will not. In this way the physical arrangement of the alternatives could be used as an aid in determining the most appropriate responses. The pretested version of the questionnaire is presented in Appendix A.

Included with the items was a question (item 1) on which the respondent as asked to indicate the nature of the problem which brought hin to the counseling facility. Only subjects who indicated (both on ftem 1 and to their counselor) that they were seeking help with problems of a psychological (personal or emotional) nature were considered to be in the population of concern.

\section{Setting}

Tro Portland counseling facilities were involved in the administration of the instrument between December 10, 1973 and Feoruary 15 , 1974.

Multromain County Family Services, an adjunct to the Court of Domestic Relations, prorides non-fee counseling for a variety of problems relating to marital and family matters. Clients served live in the metropolitan area and constitute a fairly reoresentativa crosssection of local nationalities and races extending from welfare recipienta through the financially-adrantaged middle class. Three counselors holding the degree of Master of Social Work particlpated; their average number of years experience being 20 .

The Portland State Oniversity Counseling Center provides non-fee student counseling for educational, rocational, and psychological problems. Although University students tend to represent many 
nationalities and races, those utilizing Counseling Center services tend to be white and middle class. Of the 15 Counseling Center questionnaires included in the final data compilation, 13 were acministered by five graduate student counselors-in-trataing and two by clinical psychologists. The student-counselors each had a minimum of one year supervised experience and were drain from programs in psychiatry, psychology, social work, and urban studies.

\section{Sample}

At each facility subjects were randomly selected after two criteria had been met; the flrst being that they must be seeking counseling for personal or emotional problems (e.g., marital dysfunction, depression) of a psychological nature and the second being that they must not have received previous counseling at the facilitg.

Administration of Instrument

Three questionnaires were administered for each subject. Each client completed a pre-intervien form in the reception room just minutes prior to their initial counseling session. At the interview's conciusion, while still in the counselor's office, both client and counselor simultanecusly completed post-interview forms (the only item dipfering on the pre- and post-forms is Item 22-see Appendix B). The counselors written and verbal instructions indicated he was to respond "as through the client's eyes; in otiner words, how you believe your client is resoonding to the post-intarview form."

cilents placed both pre- and post-interview forms in sealed envelopes and nelther client ror counselor saw each other's ratings. 
Scoring

The items were then scored and the total expectancy scale score cesignated as the sum of the 12 1tems asterisked in Appenct. A. Subsequent to instmment administration and evaluation, these 12 itams were selected as representing the most diract, clear, and unambiguous questions or statements and alternative responses regarding expected therapeutic gain and, when considered in cluster, provide the best single measure of total expectancy. The total score for an individual could range between 12 and 48 , with one point intervals (and half point intervals in the very fes cases where a respondent chose tio adjacent alternatives for the same item). 
RESULTS

Table 1 and Table 2 indicate the expectancy scale results for the two counseling facilities. Two trends are apparent. First, that the client's expectation regarding the outcome of counseling is higher at the conclusion of the initial counseling interview than just prior to it; 22 of the 30 clients showing some degree of increased expectancy with five showing no orerall change and three shoxing slight decreases. Second, the most significant finding of the study is that the counselors consistertiy rate the client's post-intarview expectancy as being much lower than the client's self-rating. The mean post-expectancy score for the client's self-rating is 39.75 and for the counselors this score is 30.62. Of the 30 counselor-rated scales, 27 estimate the client's postexpectancy as teing lower than the client's perception shile one rating is the same and two show a one point higher estimate. 1

For analytic purposes the colunns of Tables 1 and 2 are mmbered consecutively and several column comparisons both within and between tables are made using t-tests and F-tests (see Table 3). (NOT:: severaI correlations were also obtained using the Parsonian product-noment coefficient of correlation. These correlations range from .10 to .61, but are not included in tinis section as an $r$ was used with the untested ssumption that these data are interval data whereas they actualig appear to be interval data. The results were inconclusige as was inpected). Colums compared are: 
Columns 1 and 5 to determine if there is any significant difference between clients of the two facilities on ortginal (entering) expectations regarding the counseling process. The null hypothesis states that the mean (t-test) or variance (F-test) for the columns compared is the same and the alternative hypothesis is that Column 1 is greater than Column 6.

Columns 3 and 8 to determine if there is any difference in first counseling interview outcome regarding client expectation between the two faciltties. The hypotheses are stated in the saine order as above. Columns 3 and 5 to determine if the NuItnomah County Family Services counselors' rating of the client is affected by the amount of client progress (or lack of) during the interview. The hypotheses are stated as abore.

Columns 8 and 10 are identical to Columns 3 and 5 except for facility.

Columns 5 and 10 to determine if there is ang difference between the facilities regarding counselor-ratings. The hypotheses are stated in the same order as above. 
TABIE 1

EXPECTANCY SCALE SUMMART

MULTNCMAI COUNTY RAMILY SERTICES

Client Client Pre/Post Counselor Counselor Post Cliant Pre-Score Post-Score Difference Post-Score Difierence

\begin{tabular}{rrrrrr}
\hline 1 & 42 & 46 & 4 & 37 & -9 \\
2 & 40 & 44 & 4 & 33 & -11 \\
3 & 43 & 43 & 0 & 33 & -10 \\
4 & 34 & 44 & 10 & 29 & -15 \\
5 & 39 & 42 & 3 & 33 & -9 \\
6 & 28 & 38 & 10 & 30 & -8 \\
7 & 46.5 & 46 & -.5 & 29.5 & -16.5 \\
8 & 26 & 29.5 & 3.5 & 24 & -5.5 \\
9 & 36 & 38 & 2 & 39 & 1 \\
10 & 31 & 31 & 0 & 31 & 0 \\
11 & 43 & 43 & 0 & 33 & -10 \\
12 & 39 & 41 & 2 & 24 & -17 \\
13 & 43 & 44 & 1 & 30 & -14 \\
14 & 33 & 36 & 3 & 29 & -7 \\
15 & 38 & 44 & 6 & 29 & -15
\end{tabular}

* Consisting of the 12 items asterisked in Appendix A. 
TAB: 2

EXPECTANCT SLAIE SUMMART

FORTLAND STATE UNIVERS TPY COUNSELING CENTER

Client Client Post/ $\begin{array}{lccc}\text { Client } & \text { Client } & \text { Pre/Post } & \text { Counselor Counselor Post } \\ \text { rre-Score } & \text { Post-Score } & \text { Difference } & \text { Post-Score Difference }\end{array}$ (6)

(7)

(8)

(9)

(10)

\begin{tabular}{llllll}
\hline 16 & 41 & 41 & 0 & 27 & -14 \\
17 & 39 & 35 & -4 & 28 & -7 \\
18 & 37 & 38 & 1 & 39 & 1 \\
19 & 31 & 34 & 3 & 23 & -11 \\
20 & 34 & 36 & 2 & 30 & -6 \\
21 & 40 & 45 & 5 & 32 & -13 \\
22 & 36 & 40 & 4 & 33 & -7 \\
23 & 35 & 41 & 6 & 34 & -7 \\
24 & 41 & 43 & 2 & 33 & -10 \\
25 & 40 & 40 & 0 & 30 & -10 \\
26 & 35 & 36 & 1 & 32 & -4 \\
27 & 37 & 38 & 1 & 30 & -8 \\
28 & 41 & 40 & -1 & 29 & -11 \\
29 & 33 & 34 & 1 & 24 & -10 \\
30 & 35 & 42 & 7 & 31 & -11
\end{tabular}

* Consists.rof of the 12 items astertuksd in Appendix A. 
TABLE 3

RESUITS OF T TESTS AND F TESTS

FROM THE DATA OF TABIS 1 AND TABLE 2

\begin{tabular}{|c|c|c|c|c|c|}
\hline \multirow[b]{2}{*}{ Column Source } & \multicolumn{2}{|c|}{ t-test } & \multicolumn{3}{|c|}{ F-test } \\
\hline & $p$ & $\mathrm{Ho}(.05)^{*}$ & $P$ & $\mathrm{Ho}(.05)^{*}$ & $\operatorname{Ho}(.01)^{*}$ \\
\hline $1 / 6$ & $p .05$ & $\operatorname{DNR}{ }^{x-7}$ & 4.05 & $R^{* * * *}$ & \\
\hline & & & $D .01$ & & DRR \\
\hline $3 / 8$ & -.05 & DNR & $D .05$ & DIR & \\
\hline $3 / 5$ & 4.05 & R & 4.05 & $\mathrm{R}$ & \\
\hline & & & $P .01$ & & DNR. \\
\hline $8 / 10$ & 4.05 & $R$ & $D .05$ & DirR & \\
\hline $5 / 10$ & -.05 & DNR & $>.05$ & DNR & \\
\hline
\end{tabular}

\footnotetext{
* The mull bypothesis states that the mean (t-test) or variance (F-test) for the columns compared is the same and the alternative hypothesis is that the first listad comparison column under "Column Source" is greater than the second.
}

Do Not Reject

**ject 
Table 3 Conclusions

t Tests

Significant differences were not found at the .05 level between clients of the two facilities on client pre-scores.

Similarly, no differences were found between facllities' clients on the pre- and post-score differences.

Also, no differences were found between facilities with respect to client versus counselor post-ratings.

There was a significant difference in each facility with respect to the client pre/post difference and the client/counselor differences in the post-ratings. This would have to be due to the counselors' underestimation of clients' expectations.

The interesting findings of these analyses is that both clients and counselors in the two facilities performed similarly on the averaga.

\section{F Tests}

The variance of Family Service clients was greater than that of the Portland State University Counseling Center at the .05 level, but not tine .01 level on pre-scores.

The variances on client pre/post and counselor/client post-scores was not signsficant at the .05 level in the Counseling Center.

Further studies wonld have to be made to determine whether these are real differences, chance, or due to differences in the statistical tests. The significance reaopears when both facilities are combined.

On the remaining tests results bore out the t-tests. A series of studies with a large population is required to settle the questions 
raised by the analysis so far-whether gains were real or spurious, whether counselors' ratings were real or affected by extrinsic considerations. It is fruitless to speculate at this point. 


\section{DISCUSSION}

The concept of expectation of treatment success for problems of a psychological nature does not readily lend itself to speciflc description or analysis. Guilford (1965) Incisively coments

The point is that success in any sphere of life is ordinarily highly complex and is determined by many psychological factors (rather than one or a few) ... We shouid, of course, attempt to single out the most significant aspects... Too often some inconsequertial aspects are chosen because of their ready observability and measurability. (p. 473)

The items selected to measure this construct for the inftial scale represent the author's conception of the construct, and to the extent that counselors and researchers agree as to their reasonableness, they have a degree or face validity.

The format of the questions is one which has been used successfully in other attitude research as it allows for inter-jubject response variance and reasonable degrees of reliability. The items were designed with sufficiently general content to allox use of the scale in settings other than those of the present study. The length of the instrument was kept short, taking approxinately three minutes to complete, as it maz be anticipated that individuals coming for counseling regarding personal or emotional problems often will be nervous, depressed, frightened, and in general not in a mood to respond accurately to a long serles of items. The exclusion of those who did not acmit to personal or emotional difficulties seemed a conceptual necessity. It would be difficult to explain.the meaning of a score indicating expectation of "getting better" 
fo: a person who didn't view himself as somehow functioning "not well" from an intrapsychic standpoint.

\section{Statistical Considerations}

The conclusion that the final scale reliably measures a single construct cannot be inferred. Two tentative estinates of internal consistency were made. 2

First, the difference of post-item 4 minus post-item 2 was obtained $(N=30, d f=29)$ and compared to the set consisting of columns 3 and 8 . Item 4 pertains to the clients' expected "future state" and item 2 their "present state." It was believed that deriving a numerical value for the soread between "nor" and "later" would approximate a measure of expected therapeutic gain. Columns 3 and 8 represent the clients' post-expectancy scale score-mims the pre-scale score; or, what can be interpreted as therapentic gain over the initial interview.

It was thought that conparing aggregate post scores for the two itoms pertaining to "now" and "later" with the pre(now)/post(later)-scale difference scores would yield a strong relationship. This presumed relationship was examined using both the paired difference t-test and tine Pearsonian correlation coefficient. The resilts of each show intuitive logic to be at variance with statistical analysis. Using the oaired difference t-test we are able to conclude at the .05 level that there is a statistically signiflcart difference between the two comparison sets. The product-moment correlation derives an $I$ of .10 . These results lead to the conclusion that either these two dimensions examined are not the same or that we are mexsuring different vartables or different aspects 
of the same variable.

Another probe into internal consistency was to coroare post-scale Item 4 ("How vell do you expect to feel about your problem(s) a month ircm now as a result of the counseing you recelve here?") to post-sczle item 12 ("I think my chances of doing better about my problem(s) because of this counseling are. . ") as they appear to be asking substantially the same question ard the alternative responses are comparable. The item 4 and Item 12 relationshio tasted with the product-moment correlation results in an $r$ of .26, which gives a $z$ score of .2661. As mentioned in RESUITS, here we are using tine untested assumption that the data are interval data.

A partial explanation for this Heak correlation perhacs hinges on the client's perception of the problem. For example, the individual might not believe his prinary difiloulty will be solved to any extent, but that the secondary problam of emotjonal distress bill (e.g., he will learn to better accomodate to the situation). Cartwright and Cartimight (i950) considered another facet of this inconsistency regarding the client's belifer that centain effects mill result rrom psychotherapy. They observe that some researchers

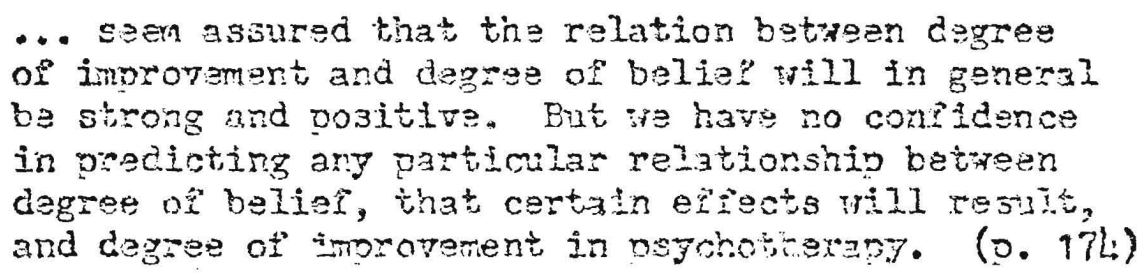

Another correlation was obtained on the single scale item rnich provideg the clearest and most direct statement the scale in total is dasigned to neasura. Post item 12, a straight-iomard expected therapeutic gain question, was compared to the post-scale score by means of 
the product-moment correlation; the logic herein being that the content of the item which semantically correlates most highly with what the scale is asking can be viewed 23 a general measure of the content of the construct measured by the scale.

The correlation $\left(r^{*} .61\right)$ in this case is moderate. The $r^{2}$ is .372 and indicates the proportion of the variation in common with the total score; $.628 \mathrm{may}$ then be an indication of the unique contribution made by this item. This conclusion might be normal as a scale is composed of different and varied elements that do not correlate or, maybe, our semantics are defective and we are in fact measuring two or more different varlables that should be given separate treatment.

The rather Iow correlations obtained above, while demonstrating a significant relationship; indicate that the measured expectancy is not a discrete phenomenon and that some independent fnformation is provided by the scale score. This author agrees with Baggaley (1964) that

For the purposes of construct validity, finding out the variables that corralate low with a particular test is as inoortant as learning the variables that correlate high with the test. (p. 68)

Another consideration regarding this author's approach deals with scale assumptions. Wert et al. (1954) caution that aralyzing items
... by correlating the responses to each item with the total test score assumes that the total score is an appropriate index of the behavior which the test has been desigred to neasure. Thus selecting items for a test which correlate high with their total score tends to ylald items which correlate hign with each other. It can then be seen, that it is only aporooriate to use a total score as a criterion shen the behavior measured by the total score is homogeneous. (p. 339) 
The presant study treats the indiridual as a composite-clustar of mood-attitude and the anticlpatory behatior measured by the scale may well not be homogeneous. The attempt is to inquire as to the nature of the Individual holistically and a composite measure yas used because people are composite, not discrete elements readily lending thenselves to Isolation and scientific analysis.

The real issue in question, then, is the construct validity of the flnal scale. Specifically, is there any reason to believe that the client's expectation of being helped is the factor that results in whatever consistency emerges in responses to scale items. Detarmining instrument reliability is not an easy task whenever attitude-bshavior research is involved and this study is confounded even more so as measurement can't be based on independent, observed changes in behavior. Therapeutic gain is dealt with only as it can be ascribed to the first interriew.

\section{Further Analysis and Resaarch Needed}

Based upon the data presented it can rasonably be concluded that the scale as tested possasses face validity and a presumed slight to moderate degree of reliability regarding client expoctation of treatment success and the counselor's perception of the cilent's expectancy stata. Results obtained cannot be negated on the conparative bast3 of prior expectaney research as this is not an extensively investigated attitude and conclusions reached are contradictory (often, seemingly a function of the theoretical orientation held by the clinical researcher).

In order to refine the scale with the viaw of raking it both oporational and useful, two requirements, in this writer's opinion, need to be pet-scale reliability and predictiva validfiy. 
Item analysis will help reach the major goals of improvement of total-score reliablitity or total-score validity, or both (Guilford, 1965). This is necessary in order to make sure that all scale items are functioning; that they are working as units of measurement and enabling differentiation between the better and poorer items. This approach is believed appropriate in the present design as such evaluation involves comparing the responses to an item when it is used in both pre- and posttests. One of the most frequentiy used statistical procedures for item analysis is that of obtaining the correlation betwren item responses and total test score. This was very selectively attempted (as there are literally hundreds of such correlations possible) for suggestive purposes via the long-hand method in the present analysis.

Factor analysis can serve the intersest of scale econong by lndicating which items can be added and studied as a unitary whole rather than separately; thus serving to limit the tangle of variables with which the researcher must cope. Analysis of this type should help to locate and identify the fundamental expectancy properties undarlying the instrument.

If the scale can be made reliable, prediction of outcome would be the next logical steo in such a research program. At present we have no confidence in predicting any particular relationship between degree of expectancy and degree of improvement through counseling. Ferhaps the most difficult aspect of the predictive-validity problem involves obtaining adequate criterla for what we are trying to measure. Tha factor-analysis spproach is one solution when a primary trait such as expectancy is that we wish to measire. The author is currently engaged 
In conputer-testing the instmment by means of the cluster method whereby clusters and presuned factors are identified by searching for interrelated groups of correlation coefificients or other measures of relation.

\section{Concluding Conments}

This study represents a tentative examination of the general hypothesis that entering client expectation is related to subsequent firstinterview counseling reaults. The author believes thers is justification for generalizing fron the single intervies to the extent it serves as a singular reflection of the overall treatment series. It is well-accepted in terms of principle that of all the counseling sessions, the first is without peer in terms of importance as it bears upon the total counseling relationship. ${ }^{3}$ The more important qusstion as it bears upon this study is whether the notion of expectancy is worth studying at all. Heine and Trosman (1960) argue that expectancy is a determinant as to whether therapy occurs or continues. Expectation may not lead directly to tiserapeutic gain, but instillation of expectancy may keep a person until nore potent forces for change cone into play. This author's opinion is that the expectation of improtement in life is very important because hope for a better future is perhaps the pring life-motivating force for many at some point in time. 
NCTES

'Perhaps this consistently lower rating by the counselor could appropriately be temed a "pessinist index." A number of factors may help account for this variation between client and counselor percepilons: the counselor's experience and therapeutic "realism" and desirs to keeo his crm expectations at a reasonable lavel; the client's "halo" reaction to the counselor; the disproportionate increase in expectancy once the client has taken the first counseling step; the possibility that a little gain may make the client feel a lot better; and, that the client is thinking subjectivaly and the counselor objectively. Chance (1960) found therapists to underestinate the amount of emotion displayed in early therapy hours. This observation bears upon the question to the extent that expectancy (anticipation, belier, hope, faith, atc.) is an emotion or has emotional overtones.

2 The test-retest method was not considered appropriate in view of the possibility that expectancy level may change significantly during the period between testings and due to the uncertainty of followup access to subjects. The split half method was not considered aporopriats due to the shortness of the scals.

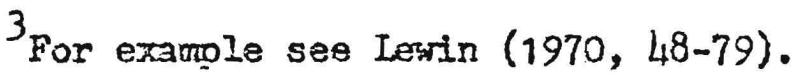


REFERENCES CITED

Aplelbaum, D. Dimensions of transfererce in osychotheraof. Unitersity of California Fress, Berkeley, 1958.

Pegsaley, A, R. Intermediate correlational methods. John-Hiley \& Sons, NIew York, 1904, 68.

Besnar, R. I. Persuasibility and the power of belief. Personnal and Guidance Joumal, 1970, 48, 647-652.

Braty, J. F., Reznikoff, M., \& Zeller, W. W. The relationship of expectation of linprorement of hospitalized psychiatric patients. Journal of Nervous and Mental Disease, 1960, 130, 41-44.

Cartiright, D. S. \& Cartwright, R. D. Faith and improvement in psychotrexapy. Journal of Counseling Psychology, 1958, 5, 174-177.

Chance, Erica. Families in treatment. Basic Books, New York, 1959.

Frank, J. D. The influence of patients' and therapists' expectations on the outcome of psyciotherapy. British Journal of Medical

Psychology, $1968,41,349-356$.

Frank, J. D., Gliedman, L. H., Imber, S. D., Stone, A. R. \& Nash, E. H. Patient's expectancies and relearning as factors determining improvement in psychotherapy. Anerican Jourrai of Psychiatry, 1959, 115, 961-968.

Gliedman, I. H., Nash, E. H., Imber, S. D., Stone, A. R. \& Frank, J. D. Reduction of symotoms by pharmacologically inert substances and by short-term psychotheraog. A.M.A. Archites of Meurology and Psychiatry, $1958,79,345-351$.

Goldstein, A. P. Therapist and client expectation of personality change in psychotherapt. Journal of Counseling Psychology, 1960, $7,180-184$.

Goldstein, A. P. Theraoist-patient expectancies in psychotheragy. Macmillan, New York, 1902.

Goldstein, A. P., \& Shipman, W. G. Patient expectancies, symptom reduction and aspects of the initial psychotherapeutic interview. Journal of Colmseling Psychology, 1961, 17, 129-133.

Cuslford, J. P. Fundamental stat,istics in 0s,7cholog ard education. MeGrax-Hill, New lork, 1955, 493-506. 
Heine, R. W. \& Trosman, H. Instial expectations of the doctor-patient interaction as a factor in the continuance of psychotherapy. Psychiatrist, $1960,23,275-278$.

Kelley, H. H. The effects of expectations upon first impressions of persons. American Psychologist, 1949, 4, 252.

Klein, M. H., Dittmann, A. T., Parloiff, M. E., \& Gill, M. M. Behavior therapy: observations ard reillections. Journal of Consulting and Clinical Psychology, 1969, 33, 259-266.

Lennard, H. L. \& Bernstein, A. The anatomy of psychotheraoy. Columbia University Press, New York, 1960.

Lewin, K. K. Brief osychotherady: brief encounters. W. H. Green, Inc., St. Louis, 1970, 48-79.

Lipkin, S. Clients' feelings and attitudes in relation to the outcome of client-centered therapy. Psychological Morograohs, 1954, 68 (1, Whole No. 372), 1-30.

Piper, W. E. \& Wogan, M. Placebo effect in psychotherapy: an extension of earlier findings. Journal of Consulting and Clinical Psychology, $1970,34,447$.

Pope, B., Siegman, A., Blass, T., \& Cheek, J. Some effects of discrepant role expectations on interviewee verbal benavior in the initial interview. Journal of Consulting and Clinical Psycholog, 1972, $39(3), 501-507$.

Reznikoff, M., Brady, J. P., \& Zeller, W. W. The psychiatric attitudes battery: a procedure for assessing atiitudes toward psychiatric treatment and hospitals. Journal of Clinical Ps7chologg, 1959, $15,260-265$.

Rosenthal, D. \& Frank, J. D. Psychotheraoy and the placebo effect. Psychological Bulletin, 1956, 53, 294-302.

Rosenthal, R. Experiment effects in behavioral research. AppletonCentury-Crosts, New York, 9966.

Sloane, R. B., Cristol, A. H., Pepernik, M. C., \& Staples, F. R. Role preparation and expectation of improvement in psycholotheraoy. Journal of Nertols and Mental Disease, 1970, 150, 18-26.

Wert, J. E., Neidt, C. C., \& Ahman, J. S. Statistical methods in educattonal and osychological research, Apoleton-Century-Crorts, Hew York, 1954, 339 . 
Wicker, A. W. Attitudes vs actions: the relationsinip of verbal and orert beharioral responses to attitude objects. Journal of Social Issues, 19ós, 25, 41-79.

Wilkins, W. Desensitization: social and cognitive factors underlying tine epfectireness of Wolpe's procedure. Psychological Bulletin, $1971,76,311-317$.

Wilkins, W. Expectancy of therapeutic gain: an empirical and conceptual critique. Journal of Consulting and Clinical Psychology, 1973, $40(1), 69-77$. 
APPEIDIX A

ERPECTANCY QUESTIONAIPE 
The purpose of these questlons is to holp us to understand what people
expect from the counselling they receive here. Please try to answer ea
the questions frankly. the questions frankly. There are no right or wrong answers. Please plece

is part of an independent atached envelop and soal it when completed. This your answers.

Please circle the letter of the alternative you choose for each question.
Your help is sincerely appreciated?

(NOTE-The term "personal problems" in some of the items refers to any emotional or nervous difficulties you may be experlencing. Examplea of these might be: getting very depressed, very angry, very tense, very

1. I am here for help with...

a. educational problems.

b. problems with my family.

c. personal or emotional problems.

d. other problems.

2. In personal matters in my daily life, I...

a. could $n^{2} t$ be better, everything is fine.

b. am getting along fairly well.

c. am not doing too well.

d. feel like I am barely getting by.

3. How helpful do you belleve your counseling here will be?

a. I am almost certain that counseling will be of help.

b. I am hopeful that counseling will be of help.

c. I am somewhat doubtful that counseling will be of help.

d. I do not really belleve that this counseling will help me.

4. How well do you expect to feel about your problem(s) a month from now as a result of the counseling you receive here?

a. Puch worse than before I came here.

b. Somewhat worse than before I came here.

c. Somewhat better than before I came here.

d. Nuch better then before I came here.

5. Do you expect to need some kind of counseling sgain within six months?

8. I definitely will require some kind of counseling within six months.

b. I probably will require counseling within alx months.

c. I probably will not require counseling within six months.

d. I definitely will not require counseling within six months.

6. The personal problem(s) I am now having. .

a. will probably affect me in some ways for the rest of my life.

b. will probably affect me for a period of from six months to several years

c. will probably affect me for a period of one to six months.

d. will probably affect me for just a few days or weeks. 


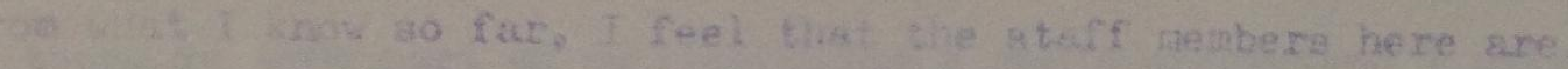
ingly sompetert.
competent.
Co faltly competent.
d. not too corupetent.

Intend to follow the sug estions of the counselors here.

a. as closely as I can because thatever they say will be helpful.

b. pretty Glosely beoause nost of theix ideals will be helpful.

c. to some extent, but a low of their ldeas probably won ${ }^{2} t$ be helpful.

i. very 11 thle because they don't know whet will be helpful to me.

9. I would encourage a friend who wauted the beat help with a problem girailax to mine to. .
Q. Imnediately Beek the type of help thut is avallable here.
b. sexlously consider this type of help.
O. seck other sources of help before coming to a place like this.
d. arola thls type of counseling if possible.

* From iy experiense or to the best of ry knowledge. I think I could do.

a. a uach better job of helpluy people than the staff here.

b. at least as good 8 job of helplng people as the staff here.

Q. no better of $\&$ job of helping people than the staff here.

d. auch leas than the ataff here is doing to help people.

11. How did you feel about youx first appointment here?
a. I iresided coning.
in I we.8 sonewhat 111 at erse about coming.
c. I had no particular feeling, elthex good or bad, about coming.
d. I feit good about coming.

$*$
$*$
$*$

2. I thing gy chunces of doins better about my problem(s) because of this counseling are...
a. extremely poor.
b. faixly poor.
c. falily grod.
d. extremely good.

I. feel that coming here for help with my problem(a).

a. 1.s one of the best things I have ever cione.

b. Is better than trying to work things out by myself.

c. is not going to be of much help.

d. $1 \mathrm{~s}$ going to be a waste of time.

14. I expect that I will need to continue some kind of counseling here for.

a. about $8 i x$ montha to a year.

b. about one to six montha.

c. a few weeks at most.

d. no longex then juat today. 
*25. If there is some part of my counseling I don't understand I wi11..

a. go along, having faith that the gtaff knows what they ${ }^{9}$ re doing.

b. go along, but feel a little unsure.

c. be very hesitant to go along.

d. refuse to cooperate.

16. I feel the staff here is probably. .

a. very concerned with melfare.

b. moderately concerned with ny welfare。

c. little concerned with my welfare.

d. unconcermed with my welfere.

17. I have been attending religious services. . .

a. about every week.

b. about once a month.

c. only on special occasions such as holidays.

d. raxely or never.

18. How willing were you to come here for counseling?

a. I was very reluctant and came only because someone else insisted.

b. I was reluctant but deoided to come just out of cusstost ty.

c. I wasn't sure about coming but felt I had nothing to 20se.

d. I wanted to come and sought counseling.

19. Just talking to someone about my problem(s) will. .

a. help me a great deal.

b. help me somewhat.

c. help me little.

d. help me not at all.

20. My friends and family...

a. were against my coming here.

b. were indifferent s.bout my coming here.

c. were glad about my coming here.

d. don ${ }^{2} t$ know $I^{0} m$ coming here.

21. I feel that the problem(s) that brought me here are...

\&. very sexious.

b. pretty serious.

c. not too serious.

d. not very serious at all.

22. After talking with ny counselor today I expect to feel。.

a. worse then I do now.

b. about the same as I do now.

d. somewhat better then I do now.

e. much better than I do now. 


\section{APYENDIX B}

POST-QUESTIONNAIRE ITEM 22

22. Right at this moment I feel. .

a. worse than before I saw ing counselor.

b. about the aame as I did before I saw my counselor.

c. somewhat better than before I sav my counselor.

d. much better than before I sat my counselor. 